\title{
ANTALYA KENT MERKEZINDE KENTSEL DÖNÜŞÜM UYGULAMALARI
}

\author{
Deniz BAYRAKTAR* , Emre Artun BAYRAKTAR**
}

\section{ÖZ}

Türkiye'de 1950'li yıllarda yaşanan kırsaldan kentlere yönelik göç hareketi, kentlerde çarpık yapılaşmaya ve altyapı sorunlarının oluşmasına neden olmuştur. Deprem, su taşkını ve toprak kayması gibi doğa olayları sonucunda yaşanan can ve mal kayıpları bu sorunlar ile yüzleşilmesini gerektirmiştir. Nitekim yakın geçmişte yaşanan 1999 Marmara Depremi, 2009 İstanbul Ayamama Deresi Taşkını ve 2011 Van Depremi, doğa olaylarının kolayca afetlere dönüşebileceğini göstermiştir. Yaşanan afetlerin öncesinde birçok yasal düzenleme hayata geçirilmiş ancak, riskli yapıların tespiti ve dönüşümü hakkında istenen düzeyde gelişme sağlanamamıştır. Nihayetinde, 2012 yılında yürürlüğe giren 6306 sayılı Afet Riski Altındaki Alanların Dönüştürülmesi Hakkında Kanun ile birlikte afetler öncesinde alınması gereken tedbirler hakkında ciddi adımlar atılmıştır. Kanunun yürürlüğe girdiği tarihten itibaren tüm Türkiye'de olduğu gibi Antalya'da da riskli alan ve yapıların tespitinde büyük ilerleme sağlanmıştır. Kanun kapsamında, Antalya kent merkezi sınırları içerisinde üç adet riskli alan belirlenmiş ve 7.000 adet dolayında yapı riskli ilan edilmiştir. Bu çalışmada; Antalya kent merkezinde mevcut yapılaşma gözlemlenmiş, yapılaşmanın genel karakteristiği değerlendirilmiş ve kent merkezinde gerçekleştirilen kentsel dönüşüm projeleri örneklenerek dönüşüm uygulamaları hakkında öneriler geliştirilmiştir.

Anahtar Kelimeler: Antalya, kentsel dönüşüm, 6306 sayılı kanun, kentleşme

*Makale Gönderim Tarihi: 24.01.2019 ; Makale Kabul Tarihi : 24.05.2019 Makale Türü: Araştırma DOI: 10.20854 /bujse. 517563

*Sorumlu yazar: Antalya Çevre ve Şehircilik İl Müdürlüğü, 07300, Antalya (deniz_ceditoglu@hotmail.com)

**Antalya Çevre ve Şehircilik İl Müdürlüğü, 07300, Antalya (emreartunbayraktar@yahoo.com) 


\title{
URBAN TRANSFORMATION IMPLEMENTATIONS IN ANTALYA CITY CENTRE
}

\author{
Deniz BAYRAKTAR* ${ }^{*}$ Emre Artun BAYRAKTAR**
}

\begin{abstract}
The migration movement from rural to cities in Turkey in the 1950s has caused unplanned urbanisation and infrastructure problems in the cities. As a result of nature events such as earthquakes, water floods and landslides, the losses of life and property have required to be faced with these problems. 1999 Marmara Earthquake, 2009 Istanbul Ayamama Creek Flood and 2011 Van Earthquake have shown that natural events can easily turn into disasters. Many legal regulations have been applied before the disasters. However, the desired development for the transformation of risky structures has not been achieved. With the Law No. 6306, which entered into force in 2012, serious steps have been taken before the disasters. As from the date the law entered into force, great progress has been made in the determination of risky areas and structures in Antalya as well as in Turkey. Under the law, three urban regeneration areas were identified within the boundaries of the city centre of Antalya and 7.000 structures was declared risky. In this study; the structuring was examined in the city centre of Antalya and the general characteristic of the structures was analysed. Urban transformation projects in the city centre have been sampled and suggestions on conversion practices have been developed.
\end{abstract}

Keywords: Antalya, urban transformation, law no. 6306, urbanization

*Makale Gönderim Tarihi: 24.01.2019 ; Makale Kabul Tarihi : 24.05.2019 Makale Türü: Araştırma DOI: 10.20854 bujse. 517563

*Corresponding author: Antalya Provincial Directorate of Environment and Urbanization, 07300, Antalya (deniz_ceditoglu@hotmail.com)

**Antalya Provincial Directorate of Environment and Urbanization, 07300, Antalya (emreartunbayraktar@yahoo.com) 


\section{Giris}

Türkiye'de 1927 yılı nüfus sayımı istatistiklerine göre kırsal nüfus toplam nüfusun \%76'sını oluşturmaktaydı. 1950'li yıllardan itibaren, tarımda yaşanan makineleşme süreciyle, kırsaldan kente yönelik gerçekleşen yoğun göç hareketleri, ilerleyen dönemlerde kentlerin nüfusunun sürekli olarak artmasına neden olmuştur [1]. Şehirleşme hızı 1950'li yıllarda değişmeye başlamış özellikle 1980 yılından itibaren daha da artmıştır [2]. Şehirleşme hızında yaşanan bu değişism, izlenen konut politikalarının da etkisiyle, şehirlerde sağlıksız ve plansız yapılaşma, altyapı yetersizliği ve gecekondulaşma sorunlarını ortaya çıkarmıştır [3]. Bu sorunlar, geçmişten günümüze Türkiye'de yaşanan doğa olaylarının afetlere dönüşmesine zemin hazırlamıştır. 1999 yılında yaşanan Gölcük ve Düzce Depremleri, depreme dayanıksız yapıların varlığını ortaya koymasının yanında afet sonrası yapılan müdahalelerin de zayıf olduğunu göstermiştir. Buna ilaveten; 2009 yılında yaşanan İstanbul Ayamama Deresi Taşkını, şehirlerin ne denli çarpık ve gelişigüzel yerleşime açıldığını da gözler önüne sermiştir.

Türkiye'de yaşanan afetler sonrasında yapı inşa kurallarının yenilenmesi amacıyla birçok yasal düzenleme hayata geçirilmiştir. 1995 yılında yaşanan Dinar Depremi sonrasında 1975 yılında yürürlüğe giren "Afet Bölgelerinde Yapılacak Binalar Hakkında Yönetmelik”, 1997 yılında bazı değişikliklere uğratılarak yenilenmiştir. 1999 Gölcük ve Düzce Depremleri sonrasında ise tamamen değiştirilerek Türk Deprem Yönetmeliği olarak da bilinen "Deprem Bölgelerinde Yapılacak Binalar Hakkında Yönetmelik” hazırlanmıştır. Bu yönetmelik, mevcutbinalarındeğerlendirilmesive güçlendirilmesi(7.Bölüm)hakkındaki hükümlerin eklenmesi ile 2007 yılında güncellenmiştir [4]. Akabinde, "Türkiye Bina Deprem Yönetmeliği" 2019 yılında yürürlüğe girmiştir [5]. Bu değişikliklere ek olarak; 27 Aralık 1999'da konut sahiplerinin zorunlu deprem sigortası yaptırmalarını hükmeden "587 sayılı Zorunlu Deprem Sigortasına Dair Kanun Hükmünde Kararname" yürürlüğe konmuş, 2001 yılında özel mülkiyete ait yapıların inşa sürecinin denetlenmesi işini tamamen değiştiren "4708 sayılı Yap1 Denetimi Hakkında Kanun" yayınlanmıştır [6]. Ancak, bu süreçte yapılan yasal düzenlemeler mevcut yapı stokundan ziyade yeni yapıların proje ve inşa süreçleri için uyulması gereken hükümleri içermektedir.
2011 yılında 644 kişinin hayatını kaybetmesi ile neticelenen Van Depremi, mevcut yapı stokunun afetler karşısındaki zayıf karakteristiğini bir kez daha göstermiş ve mevcut sağlıksız yapılaşmanın bir an önce ortadan kaldırılmasını zorunlu hale getirmiştir.

31 Mayıs 2012 tarihinde yürürlüğg giren "6306 sayılı Afet Riski Altındaki Alanların Dönüştürülmesi Hakkında Kanun” ile mevcut yap1 stokunun yapı sahiplerince veya Bakanlıkça (Çevre ve Şehircilik BakanlığıÇŞB) yapı veya alan bazında yenilenmesi öngörülmüştür [7]. Böylelikle, kentlerde sağlıksız yerleşim koşullarını ve düşük nitelikli yapı kalitelerini iyileştirmek amacıyla kentsel dönüşüm çalışmaları başlatılmıştır [3]. Kentsel dönüşüm; imara aykırı, teknik altyapı ve diğer donatılardan yoksun kentsel bir alanın, modern şehircilik anlayışı ile ekonomik ve toplumsal eylemleri de dikkate alarak oluşturulacak planlar kapsamında altyapı koşullarının iyileştirilerek afet riskinin azaltılması amaciyla, yenilenmesi şeklinde tanımlanabilir [2, 3, 6, 8, 9, 10]. Altyapı yetersizlikleri, plansız yerleşim, gecekondu türü sağlıksız ve dayanıksız yapılaşma, sosyal donatıların yetersizliği gibi sorunların bir arada olduğu yerleşim alanları potansiyel kentsel dönüşüm alanlarını oluşturmaktadır. 6306 sayılı kanun, ekonomik ömrünü tamamlamış ve yapısal direncini yitirmiş zayıf yapıların yenilenebilmesine imkân tanıması sebebiyle, muhtemel afetler öncesinde tedbirlerin hızlı ve pratik bir şekilde alınması yönünden takdir toplarken dönüşüm uygulamalarında yaşanan hak kayıplarının artarak devam etmesinden dolayı eleştiri almıştır. Ancak, Türkiye nüfusunun büyük bir çoğunluğunun deprem riski yüksek alanlarda yaşadığı ve geçmişte yaşanmış yıkıcı etki yaratan afetler göz önüne alındığında, 6306 sayılı kanunun can güvenliğini öncelikli olarak kabul ettiği düşünülebilir. Diğer bir deyişle, kanun ile afetler karşısında dayanıklı yapılar ve yerleşim alanları oluşturulması hedeflenmiştir. Düzenleme, riskli alan tespiti ve bu alanlarda oluşturulacak planlar ile kentsel yenilemeye imkân tanımaktadır. Bu kapsamda, Çevre ve Şehircilik Bakanlığı'na ve Bakanlığın verdiği yetki ile Belediyelere, varlı̆̆ını halen sürdüren sağlıksız ve plansız yapılaşma alanlarını bir bütün olarak dönüşüme tabi tutarak altyapı sorunu olmayan modern şehircilik anlayışı ile planlanan afetlere karşı dayanıklı yerleşimleri oluşturabilmesi yetkisi tanınmıştır. Diğer bir deyişle, kanun ile afetler karşısında dayanıklı yapılar ve yerleşim alanları oluşturulması 
hedeflenmiştir. Düzenleme, riskli alan tespiti ve bu alanlarda oluşturulacak planlar ile kentsel yenilemeye imkân tanımaktadır. Bu kapsamda, Çevre ve Şehircilik Bakanlığı'na ve Bakanlığın verdiği yetki ile Belediyelere, varlığını halen sürdüren sağlıksız ve plansız yapılaşma alanlarını bir bütün olarak dönüşüme tabi tutarak altyapı sorunu olmayan modern şehircilik anlayışı ile planlanan afetlere karşı dayanıklı yerleşimleri oluşturabilmesi yetkisi tanınmıştır. Bu yetki ile Türkiye'de birçok anakent ve kent belediyesi kentsel dönüşüm projelerine öncelik vermiş ve sayısı giderek artan dönüşüm projelerini hayata geçirmişlerdir. $\mathrm{Bu}$ kentlerin arasında turizm potansiyeli ve tarımsal faaliyetlerin fazla olduğu Antalya da bulunmaktadir.

1980 yılından itibaren gelişen turizm faaliyetleri nedeniyle bölgesinde göç alan şehir konumunda bulunan Antalya'da, yaşanan bu göç hareketleri neticesinde özellikle kentin kuzey kesimlerinde gecekondu tarzında mühendislik hizmeti almamış yapılaşmanın olduğu yerleşimler belirmiştir [11]. 6306 sayılı Kanun sonrası Antalya kamuoyunda bu alanların dönüştürülmesi isteği uyanmıştır. Bu doğrultuda, başta Büyükşsehir Belediyesi olmak üzere ilçe belediyeleri riskli alan tespiti yönünde arazi ve plan çalışmaları gerçekleştirmektedir. Buna ek olarak; bireysel başvuru yoluyla il sınırları içerisinde riskli yapılar tespit edilmekte ve mülk sahiplerince yenilenmektedir. $\mathrm{Bu}$ çalışmada; Antalya kent merkezinde mevcut yapılaşma gözlemlenmiş, yapılaşmanın genel karakteristiği değerlendirilmiş ve kent merkezinde 6306 sayılı kanun kapsamında gerçekleştirilen kentsel dönüşüm projeleri örneklenerek gelecekte planlanması muhtemel dönüşüm uygulamaları hakkında öneriler geliştirilmiştir.

\section{Türkiye'de Kentsel Dönüşümün Tarihsel Süreci}

Türkiye'de kentsel dönüşüm uygulamalarının, Avrupa ülkeleri ile karşılaştırıldığında, çok daha yakın geçmişte başladığı ifade edilebilir [12]. Türkiye'de geliştirilen ilk kentsel dönüşüm stratejileri daha çok gecekondu alanları üzerine yoğunlaşmış ve 1966 y1lında yayımlanan "775 sayılı Gecekondu Kanunu" yürürlüğe konulmuştur. Bu kanun ile her ne kadar plansız alanlardaki yapılaşma sorunu çözümü hedeflense de ne yazık ki gecekondu alanlarının genişlemesine engel olunamamış ve mevcut alanların tasfiyesi sağlanamamıştır [3]. Yasadışı konut bölgeleri olan gecekondu alanlarının dönüşümüne imkân sağlayan 775 sayılı kanun kapsamında; 1970'li yıllarda 20.000 ha alanda 640 gecekondu önleme bölgesi belirlenmiş, dar gelirli aileler için 30.762 adet konut inşa edilmiş ve 202 tasfiye bölgesi gecekondu türü yapılaşmadan temizlenmiştir [13].

1980’li yıllardan itibaren kentsel dönüşüm kavramı kamuoyunu meşgul etmeye başlamış ve ilk adım 1984 yılında yayımlanan "2981 sayılı İmar ve Gecekondu Mevzuatına Aykırı Yapılara Uygulanacak Bazı İşlemler ve 6785 Sayılı İmar Kanununun Bir Maddesinin Değiştirilmesi Hakkında Kanun" ile atılmıştır [2, 12]. Bu kanun ile gecekondu alanlarında ıslah imar planı yapma imkânı doğmuş olsa da yapılan kentsel dönüşüm uygulamaları fiziksel dönüşümün ötesine geçememiştir [2]. Aynı zamanda, 1980 sonrası yapılan diğer yasal düzenlemeler ile gecekondu alanlarına taputahsis belgesiverilmişve buuygulama tüm kaçak yapıları içerecek şekilde genişletilmiştir. Bu itibarla 1980 ile 2000 yılları arasında yaşanan süreç imar affı dönemi olarak da anılabilir [13]. $\mathrm{Bu}$ uygulamalar ile gecekondu alanlarındaki mülkiyet sorunlarının çözümü hedeflenmiştir. 1980'li yıllardan itibaren gerçekleştirilen kentsel dönüşüm uygulamalarına kamunun öncülüğünde gerçekleştirilen Ankara'daki Dikmen Vadisi ve Portakal Çiçeği Vadisi Projeleri örnek gösterilebilir [14]. Bu projeler, İmar Kanununun 18. Maddesi hükümleri doğrultusunda imar hakları toplulaştırılması ile birlikte bölgede var olan tüm imar hakları projeler bazında birleştirilerek projeler ile yaratılan değerin arsa sahipleri, özel sektör ve kamu arasında paylaşılması şeklinde uygulanmıştır [6, 12, 15]. 1984 yilında yayımlanan "2985 sayılı Toplu Konut Kanununa” dayanılarak 1990 yılında Toplu Konut İdaresi (TOKI) kurulmuştur. TOKİ, ilgili kanun ile birlikte dar gelirli ailelerin konut ihtiyacını karşılamayı, konut edindirme kredisi vermeyi ve gecekondu alanlarının dönüşümünü gerçekleştirmeyi hedeflemiştir. İstanbul-Halkalı, Ankara-Eryaman ve İzmir-Mavişehir bölgelerinde gerçekleştirilen sosyal konut uygulamaları bu kapsamda gerçekleştirilmiştir [13]. Kamu-Kamu (Ankara Büyükşehir Belediyesi-TOKİ) ortaklığı çerçevesinde yürütülen kentsel dönüşüm projesi için 2004 yılında "5104 sayılı Kuzey Ankara Girişi Kentsel Dönüşüm Projesi Kanunu” yürürlüğe konmuştur. $\mathrm{Bu}$ kanun aslında 2012 yılında yayımlanan 6306 sayılı kanunun bir nevi küçük ölçekli pilot uygulaması olarak kabul edilebilir. 2012 yılında yayımlanan 6306 sayılı kanun ile 1980-2000 yılları arasında yaşanan imar afları dönemindeki kentsel dönüşüm mevzuatlarından 
farklı olarak hem alan bazında hem de yapı ölçeğinde yenileme uygulamalarının önü açılmıştır $[3,13]$.

$\mathrm{Bu}$ kapsamda, Cumhurbaşkanlığı ve Bakanlar Kurulunca 2018 yılı itibari ile 184 adet riskli alan, 89 adet kentsel dönüşüm ve gelişim proje alanı ve 6 adet yenileme alanı ilan edilmiştir [16].

\section{3. Çalışma Alanı: Antalya Kent Merkezi}

\section{1 Çalışma Alanına Ait Bilgiler}

Antalya kent merkezi; batıda Beydağları, kuzeyde Toros Dağları, doğuda Serik ilçesine dek uzanan düzlükler ve güneyde Akdeniz ile sinırlanmıştır. Batıda Kemer, Kumluca ve Korkuteli ilçeleri, doğuda ise Serik ilçesi ile sınırlanan kent merkezinde, Aksu, Döşemealtı, Kepez, Konyaaltı ve Muratpaşa ilçe belediyeleri mevcuttur (Şekil 1).

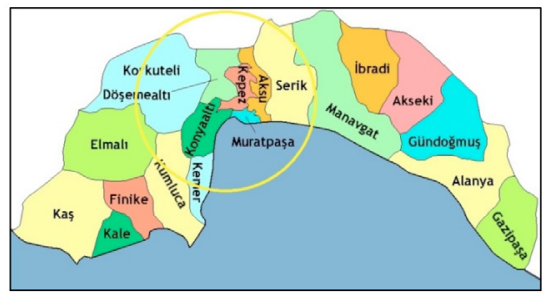

Şekil.1 Antalya ili mülki idare yapısı [17]

Kent, yüksekliği deniz seviyesinden 120 m'ye kadar ulaşan antik traverten teras ve bu ilk terastan sonra başlayarak en yüksek rakımı 350 m olan karstik ikinci teras üzerinde kuruludur [18] (Şekil 2). Antalya ilinin kıyısı asimetrik olup uzunluğu yaklaşık, girinti-çıkıntı dâhil, 640 kilometredir. Antalya kent merkezinin ise bu kıyı şeridinin ortasında konumlandığı ifade edilebilir.

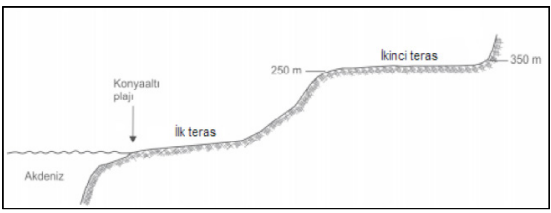

Şekil.2 Antalya kent merkezi ilk ve ikinci teras oluşumu [19]

Kent merkezi, 2017 y1lı itibari ile 1.311.471 nüfusa sahiptir [20]. 2017 y1lı Adrese Dayalı Nüfus Kayıt Sistemi (ADNKS) verilerine göre nüfus yoğunluğu en fazla olan ilçe 5.311 kişi/km2 değeri ile Muratpaşa'dır (Tablo 1) [20,21].

\begin{tabular}{ccccc}
\hline İlçe & $\begin{array}{c}\text { 2017 yılı } \\
\text { nüfusu } \\
\text { (ADNKS) }\end{array}$ & $\begin{array}{c}\text { Yüzölçümü } \\
\left(\mathbf{k m}^{2}\right)\end{array}$ & $\begin{array}{c}\text { Nüfus } \\
\text { yoğunluğu } \\
\text { (kişi/km² }\end{array}$ \\
\hline $\mathbf{1}$ & Kepez & 519.966 & 398 & 1.306 \\
$\mathbf{2}$ & Muratpaşa & 488.670 & 92 & 5.311 \\
$\mathbf{3}$ & Konyaaltı & 172.920 & 562 & 307 \\
& Aksu & 69.967 & 445 & 157 \\
\hline
\end{tabular}

Tablo.1 İlçe nüfusları ve nüfus yoğunlukları [20,21]

Anakent merkezinde yer alan Konyaaltı, Muratpaşa ve Aksu ilçelerinin denize kıyısı mevcuttur. Bu ilçeler, her yönüyle Antalya kent merkezinin turizm potansiyelinde önemli bir yer tutmaktadır. Aksu ilçesini diğer yerleşimlerinden ayıran en önemli özellik; ilçede tarım faaliyetlerinin yoğun bir şekilde devam ettirilmesidir. İlçenin sahil bandı turizm tesisleri, kuzey kesimi ise tarım arazileri ile şekillenmiştir. Döşemealtı ilçesi ise yeni yapılaşan yerleşimlerden olup, ilçe merkezindeki yapılaşma geçmiş yıllarda oluşturulan imar planları doğrultusunda çoğunlukla tek veya iki katlı konutlardan oluşmaktadır.

\subsection{Kent Merkezinde Depremler}

Antalya kent merkezi; 1947 yılında yayımlanan Yersarsıntısı Bölgeleri Haritasında tehlikesiz bölgeler sınıfında gösterilmiş, 1972 Türkiye Deprem Bölgeleri Haritası kapsamında 4. derece (5 derece bölge içerisinde) deprem bölgesi olarak sınıflandırılmış ve 1996 Deprem Bölgeleri Haritasında 2. derece deprem bölgesi olarak tanımlanmıştır [22, 23]. 18 Mart 2018 tarihinde Afet ve Acil Durum Yönetim Başkanlığı'nca (AFAD) yayımlanan 2019 Yılı Türkiye Deprem Tehlikesi Haritasında (TDTH) ise "düşük ve yüksek tehlike" arası bir sınıflandırmada tanımlanmıştır [24] (Şekil 3). 


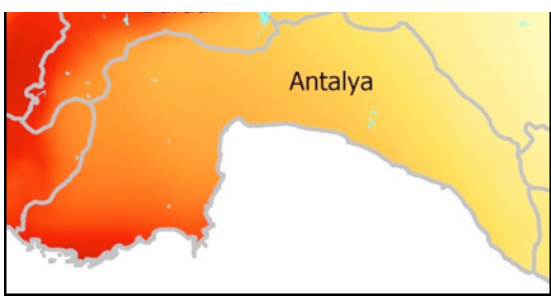

Şekil.3 Antalya ili 2019 Türkiye Deprem Tehlikesi Haritası [24]

Boğaziçi Üniversitesi Kandilli Rasathanesi ve Deprem Araştırma Enstitüsü Bölgesel DepremTsunami İzleme ve Değerlendirme Merkezi (BÜ KRDAE BDTIM) verilerine göre 1900 ile 2015 yılları arasında; Antalya merkezli $100 \mathrm{~km}$ yarıçaplı dairesel alanda büyüklüğü 4.0 ve üzeri olan 122 adet deprem kaydedilmiştir (Şekil 4). $\mathrm{Bu}$ depremlerin 101 adedi büyüklüğü 4.0-4.9; 20 adedi büyüklüğü $5.0-5.9 ; 1$ adedi büyüklüğg̈ 6.0-6.9 aralığında olan depremlerdir [25]. Ayrıca, Maden Tetkik Arama Genel Müdürlüğü̈nce 2012 yılında yenilenerek yayımlanan Yenilenmiş Diri Fay Haritaları, Antalya kent merkezini de etkileyebilmesi muhtemeldepremleri üretebilecek diri fay hatlarının varlığını göstermektedir. Kaş ilçesinin doğusunda yer alan Kasaba Havzasının güneyinde $18 \mathrm{~km}$ uzunluğunda diri fay hattı bulunmaktadır. Bu fay hattının güney yönünde Kekova Adasının kuzeyinde de diri fay hattı mevcuttur. Aynı zamanda, Antalya iline komşu Burdur ve Isparta'da yer alan Burdur ve Senirkent-Uluborlu (Isparta) diri fay hatları da kent merkezine yaklaşı $100 \mathrm{~km}$ uzaklıktadır [26].

Dipova ve Cangir, Antalya ve çevresinde tanımladıkları sismotektonik bölgeler içinde 1900-2010 yılları arasında gerçekleşen depremleri dikkate alarak istatistiksel yöntemlerle tehlike analizi gerçekleştirerek Antalya kent merkezinin depremselliğini inceledikleri çalışmalarında; Antalya'yı merkez kabul eden 100 km yarıçaplı dairesel alan içinde 5 büyüklüğünde bir depremin 10 yıl içinde meydana gelme olasılığının \%71, en az 6.5 büyüklüğündeki bir depremin 50 yıl içinde meydana gelme olasıllığının ise $\% 15$ olduğunu tahmin etmişlerdir [27].

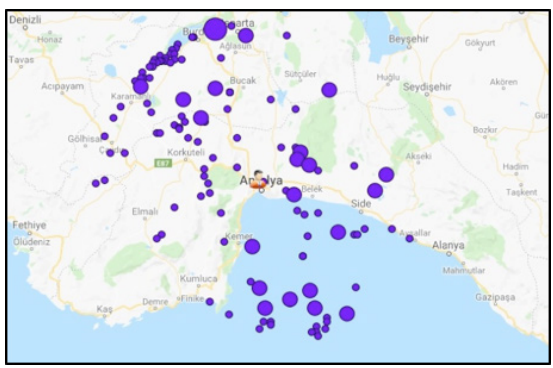

Şekil.4 1900-2015 yılları arası Antalya merkezli 100 $\mathrm{km}$ yarıçaplı dairesel alanda meydana gelen depremler [25]

Yukarıda sunulan bilgiler kapsamında; Antalya kent merkezinde yıkıcı ve hasar verici etki yaratan yer hareketlerinin yaşanabileceği görülmektedir. Hâlihazırda kente ait "Deprem Master Planı" bulunmamaktadır. $\mathrm{Bu}$ doğrultuda, hazırlanması muhtemel "Deprem Master Planı" öncesinde kent merkezindeki yapılaşma alanlarının jeolojik ve geoteknik yönden incelenmesi ve inceleme sonuçlarına uygun imar koşullarının oluşturulması önem arz etmektedir. Ayrıca, Antalya kent merkezinde genel hayatı etkileyebilecek bir afet sonucunda, afetten etkilenecek vatandaşların barınma, toplanma ve diğer ihtiyaçlarını karşlanabileceği afet toplanma merkezi veya alanı bulunmamaktadır.

\subsection{Kent Merkezinde Sel ve Taşkın Tehlikesi}

Antalya kent merkezi sınıları içerisinde, özellikle 1990'lı yllardan itibaren, hasar yapan birçok sel ve taşkın afeti de meydana gelmiştir. 27 Mayıs 1993, 3-4 Kasim 1995, 20-24-29 Kasim 2001, 2326 Aralık 2003 ve 8 Şubat 2010 tarihlerinde Aksu Çayı, Boğaçay ve Kemer Ağva Deresinde meydana gelen seller neticesinde anakent merkezinde önemli düzeyde altyapı hasarları oluşmuştur [28]. Antalya kent merkezi, sirasıyla doğusunda ve batısında yer alan Aksu Çayı ve Boğaçay akarsu havzalarında yaşanan taşkınlardan etkilenmektedir. Boğaçay, Göksu ve Çavdır Çaylarının Konyaaltı ilçesi Zümrüt Mahallesinde birleşimi ile oluşan akarsudur. 2003 yilında yaşanan taşkında Boğaçay'dan geçen maksimum debi 1.899,94 m3/sn olarak ölçülmüştür [28]. Antalya kent merkezinde gerçekleştirilen sağliklaştırma ve yeniden canlandırma projeleri içerisinde yer alan Boğaçay Çevre Düzenlemesi 
Projesi kapsamında Boğaçay taşkın koruma yapıları da yer almaktadır. Buna ilaveten; Devlet Su İşleri 13. Bölge Müdürlüğü tarafından Boğaçay ve kolları Çandır, Karaman ve Doyran çaylarında koruma yapıları inşa edilmiştir. Boğaçay üzerinde yer alan ve Antalya'nın batı ilçeleri ile karayolu ulaşımını sağlayan köprünün 23-26 Aralık 2003 tarihinde yaşanan sel afetinde yıkılması bu taşkın koruma yapılarının önemini göstermektedir (Şekil 5).

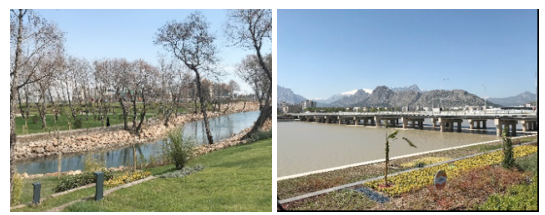

Şekil.5 Boğaçay Çevre Düzenlemesi Projesi ve Boğaçay Köprüsü

3-4 Kasım 1995 ve 8 Şubat 2010 tarihlerinde Aksu Çayı'nda yaşanan taşkınlarda Aksu Ovasının büyük bir bölümü sular altında kalmıştır. Bu tarihlerde Aksu Çayı'nda taşkın debileri sırasıyla $3.724 \mathrm{~m} 3 / \mathrm{sn}$ ve 920 m3/sn olarak hesaplanmıştır [28].

Antalya ili sınırlarında yer alan akarsularda meydana gelebilecek sel ve taşkınlara karşı önlemler, Devlet Su İşleri 13. Bölge Müdürlüğü ve Antalya büyükşehir Belediyesi'nin yürüttüğü taşkın koruma projeleri ile birlikte gerçekleştirilmektedir.

Lloyd's Şehir Risk Endeksi (Cambridge Üniversitesi Risk Araştırmaları Merkezi'nce yönetilen ve dünyada 301 kenti kapsayan 2015-2025 yılları arasında insan ya da doğa kaynaklı yaşanabilecek afetler sonucunda meydana gelmesi muhtemel maddi kayıpları gösterir risk oranı) raporuna göre; 650 milyon dolarlık gayrisafi yurtiçi hâsıla kaybı ile deprem, Antalya için birinci derecede ekonomik risk oluşturmaktadır. $\mathrm{Bu}$ ekonomik kayıp, tüm risk grupları içerisinde \%36,04 paya sahiptir. Ayrıca, raporda kentte yaşanabilecek bir sel felaketinin de 30 milyon dolarlık gayrisafi yurtiçi hâsıla kaybı yaratacağı tahmin edilmiştir [29].

\subsection{Kent Merkezinin Kentleşme Süreci ve Mevcut Yapılaşma}

Antalya kent merkezinde, 1950'lerden sonra kamu eliyle Antbirlik, Pamuklu Dokuma Fabrikası, Ferrokrom Fabrikası gibi sanayi ve tarım yatırımları gerçekleştirilmiştir. Bu yatırımların etkisiyle yaşanan göç hareketlerine bağlı olarak kentin yayılma alanı 1950 yılında 270 ha iken 1960 yılında 690 ha'a, kent merkezinin nüfusu \%85 oranında artış göstererek 27.515'ten 50.908'e ulaşmıştır [30].
$\mathrm{Bu}$ dönemde; sanayi yatırımlarında çalışabilmek amaciyla Antalya'ya göç ile gelen nüfusun kendi konut ihtiyaçlarını karşılamak üzere yapmış oldukları gecekondu türü yapılar, kentte ilk plansız yapılaşma örneklerinin ortaya çıkmasına neden olmuştur [30]. Cumhuriyetin ilk yıllarında anakent merkezindeki ilk yerleşimler; bugün ki Selçuk (Kaleiçi-Old Town), Kılınçarslan, Balbey, Elmalı, Haşimişcan, Kışla, Gençlik ve Barbaros Mahallelerinden oluşmaktaydı (Şekil 6). 1950 ile 1960 yılları arasında - bu ilk yerleşimlere sınır - Bahçelievler, Memurevleri, Yıldız, Varlık, Deniz, Üçgen, Muratpaşa, Eyiler, Sinan, Zerdalilik, Çaybaşı ve Yüksekalan Mahallelerinde yerleşim alanları gelişmiştir (Şekil 6). Aynı zamanda; 1950'li yılların sonunda kentin kuzey kesimlerinde (günümüzde Antalya-Burdur karayolunun doğu ve batısında yer alan Ahatlı, Göçerler ve Kepezaltı bölgeleri) gecekondulaşma başlamıştır [30]. Kentte çarpık yapılaşma, 1960 ve 1970'li yıllarda da devam etmiş, özellikle 1976 yllında Organize Sanayi Bölgesinin kurulması ve Güney Antalya Turizm Gelişim Projesi'nin ilan edilmesi ardından 1980’li yıllarda artıs göstermiştir. Antalya, 1980'li yıllarda yaşanan turizm patlamasından en fazla etkilenen kentlerden birisi olmuştur [11]. 1990'lı y1llarda turizm sektörünün hızlı gelişimi ile birlikte kentte rant artışı olmuş ve imar planlarında turizm tesis alanı olarak ayrılan bölgeler konut alanına dönüştürülmüştür. Bu dönem sonrasında Antalya'da kent sorunları ile mücadele başlamıştır [30].

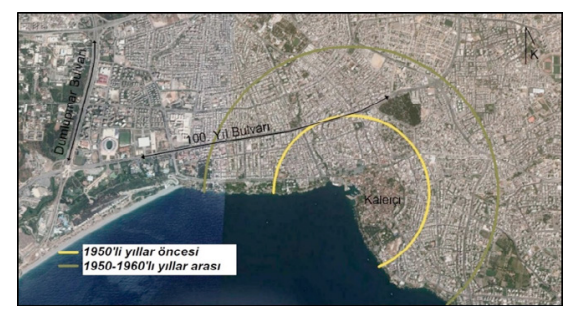

Şekil.6 Antalya kent merkezinin 1950’li yıllar öncesi ve sonrasındaki kentsel gelişimi

1950'li yllardan itibaren başlayan ve 1980 'li ylllarda gelișen turizm faaliyetleriyle birlikte hızlı bir şekilde devam eden göç hareketleri, Antalyảda nüfusun hızı bir şekilde artmasına ve buna ilaveten gecekondulaşan yerleşim bölgelerinin oluşmasına neden olmuştur. Göç ile kente gelen nüfusun hılı ve ucuz bir şekilde barınma ihtiyacını giderebilmeleri için herhangi bir mühendislik hizmeti almadan inşa ettikleri binalar zamanla geniş yerleşim alanlarına dönüşmüştür. Bu yerleşim alanlarına kent merkezinin kuzey kesimlerinde günümüzde 
Antalya-Burdur karayolunun doğu ve batı yönlerinde Kepez ilçe sınırları içerisindeki Fatih, Ahatlı, Göçerler, Çamlıbel, Erenköy, Yavuz Selim, Kazım Karabekir ve Kanal Mahallelerinde rastlamak mümkündür. $\mathrm{Bu}$ mahalleler, Kepez ilçesi yüzölçümünün yaklaşık \%3,4’ünü, 2017 yılı ADNKS verilerine göre 61.686 kişilik nüfus ile ilçe toplam nüfusunun \%12'sini oluşturmaktadır [20, 21]. Göçerler, Çamlıbel ve Kanal Mahallelerinde sahada gözleme dayalı olarak yapılan inceleme neticesinde mühendislik hizmeti almadan basit yapı malzemeleri ile tek veya iki katlı şekilde genellikle kargir sistemde inşa edilmiş yapılara sıklıkla rastlanılmıştır. Ayrıca, bu bölgelerde yaşanan sorunların başında altyapı yetersizlikleri gelmektedir. İçme suyu şebekesi, kanalizasyon hatları, ulaşım, sosyal donatılar, eğitim ve sağlık tesisleri gibi ana gereksinimler anakent ve ilçe belediyelerince sınırlı bir şekilde karşılanmaktadır. Antalya kent merkezinin iki doğal teras şeklindeki düzlüklerde kurulu olduğu düşünüldüğünde kent merkezinin kuzey kesimlerinde belirmiş gecekondulaşan alanların ilk düzlüğün sınırında yer aldığı belirtilebilir. $\mathrm{Bu}$ doğal sınır, kent merkezinin gelişimi açısından da yapay bariyer oluşturmaktadır. Aynı zamanda, bu alanların kent merkezine karayolu ile ulaşımın sağlandı ̆̆ güzergâhında yer alması kent siluetini de olumsuz yönde etkilemektedir. Nüfusun hızlı artışı anakent merkezinin yayılmasına ve altyapısı sınırlı hızlı yapılaşmaya yol açmıştır. Batıda Beydağları ve doğuda tarıma elverişli topraklar ile sınırlanan kent merkezinin gelişme sahası da bu sağlıksız ve plansız yapılaşma alanlarının yer aldığı bölgelere ulaşmıştır.

Mevcut konumları itibari ile konut alanları ile sınırlanmış sanayi siteleri bulunmaktadır. Yaklaşık 185 ha alanda kurulu olan Akdeniz ve Yeşil Antalya Sanayi Siteleri, Kepez ilçesinde yeni yapılaşan alanlardan Şafak ve Ünsal Mahalleleri ile kentsel dönüşüm projesinin uygulandığ ${ }_{1}$ Kepez-Santral Mahalleleri ile çevrelenmiş durumdadır. Eski Sanayi Sitesi olarak da bilinen yaklaşık 41 ha büyüklüğe sahip sanayi bölgesi Muratpaşa ilçesinde Cumhuriyet, Sedir ve Dutlubahçe Mahalleleri ile sınırlanmıştır. Söz konusu sanayi alanları, kent gelişimine ve ulaşımına da olumsuz etki yapmaktadır.

Antalya'da kent ticaretinin merkezi konumundaki Muratpaşa ilçesinde bulunan eski yapı kuralları ile inşa edilmiş yapıları içeren mahalleler, gecekondulaşan alanlar dişında diğer dikkate alınması gereken bölgelerdir. Sahada gözleme dayalı olarak yapılan inceleme neticesinde yürürlükte olmayan yapı kuralları ile inşa edilmiş yapıların Bahçelievler, Yıldız, Varlık, Muratpaşa, Güvenlik, Memurevleri, Üçgen, Altındağ, Deniz, Kızılsaray, Kışla, Yüksekalan, Sinan, Sedir ve Gençlik Mahallelerinde yoğunlaştı̆̆ı görülmüştür. $\mathrm{Bu}$ mahalleler, 2017 yılı ADNKS verirlerine göre 116.605 kişilik nüfus ile Muratpaşa ilçesi toplam nüfusunun \%24'ünü oluşturmaktadır [20, 21]. 1950'li yıllar ile turizm faaliyetlerinin başladığı 1980'li yıllar arasında iskân edilen bu mahallelerde bulunan yapıların günümüzde yürürlükte olmayan yapı kuralları ile inşa edildiği bilinmektedir. $\mathrm{Bu}$ yapılar, geçmiş dönemlerdeki imar şartlarına göre ruhsatlandırılmış olmasına rağmen günümüz iskân kuralları ile çelişmektedir. Bina çekme mesafelerindeki yetersizlikler, bitişik nizam ve denize paralel yapılaşma, rüzgâr akışının kuzeye yerleşik alanlara ulaşmasını engelleyen yapay bariyer durumundadır. Aynı zamanda, eskimiş ve bakımsız durumda olan yapılar, kent merkezi siluetini de olumsuz yönde etkilemekle birlikte günümüz şehir mimarisine de uymamaktadır. Nitekim Muratpaşa Belediyesince 100. Yil Bulvarı'ndan başlayarak Mevlana Caddesi'ne kadar uzanan yaklaşık $5 \mathrm{~km}$ yol boyunca yer alan binaların dış cephesi boyanmıştır.

Konum ve ekonomik canlılık itibari ile Antalya ilinin merkezi durumunda olan Selçuk (Kaleiçi), Barbaros, Kılınçarslan, Elmalı, Haşimişcan ve Balbey Mahalleleri kentsel ve arkeolojik sit alanları içerisinde yer almaktadır. Ayrıca, bu alanlara komşu Haşimişcan Mahallesi sınırları içerisinde yer alan Karaalioğlu Parkı 1. ve 3. Derece Doğal Sit Alanı, Deniz Mahallesi sınırları içerisinde yer alan Konyaaltı Falezler Bölgesi de 1. Derece Doğal Sit alanı durumundadır [31, 32]. Antalya, 2017 yılı verilerine göre toplam 819 adet sit alanı ile Konya ve Muğla illerinin ardından en fazla sit alanına sahip il konumundadır [33]. Büyükşehir Belediyesince söz konusu mahallelerde, kapsamlı restorasyon çalışmaları için kentsel tasarım ve yenileme projeleri geliştirilmektedir. 2015 yılında Selçuk (Kaleiçi) Mahallesinde Kaleiçi Hıdırlık Sokak Kentsel Tasarım Projesi kapsamında sokak yenilemesi ve peyzaj düzenlemeleri gerçekleştirilmiştir. Buna ilaveten; Balbey, Yüksekalan ve Tahılpazarı Mahallerinin bir kısmını kapsayan Balbey Mahallesi Kentsel Yenileme Projesine, 2015 yılında Resmi Gazetede yayımlanan "yenileme alanı ilanı" ile başlanmış, hak sahipleri ile ön protokol işlemleri devam etmektedir [34]. 


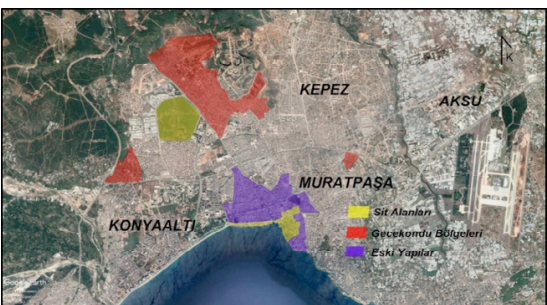

Şekil.7 Antalya kent merkezinde yapılaşma alanları

Antalya Havalimanı ile Aksu Çayı arasında kalan bölgede yer alan Kemerağzı ve Mandırlar Mahalleleri, Aksu ilçe sınırlarında tarım faaliyetlerinin sürdürüldüğü bölgeler arasında yer almaktadır. Bölgenin kent merkezinin yapılaşma güzergâhında yer alması ve turizm tesisi sayısını sürekli artması, tarıma elverişli bu bölgeleri yeni yapılaşmaların tehdidi altında bırakmaktadır. Bölgedeki yapılar, tarım faaliyetlerini sürdürenlerce inşa edilmiş tek veya iki katlı yığma yapılardan oluşmaktadır. Aynı zamanda, bölgenin kıyı düzlüklerinde turizm tesisleri de faaliyet göstermektedir. Bölgenin turizm tesislerine ve havalimanına yakın mesafede olması ve Muratpaşa ilçe sınıları içerisindeki hızlı ve yeni yapılaşan bölgelere komşu olması gibi nedenlerle inşaat projeleri için rantı yüksek durumdadır.

Antalya kent merkezinde yeni yapilaşan alanlar da mevcuttur. Yeni yapılaşan alanlar, bu çalışmanın konusu olmayip kent merkezinin genelinde, özellikle Konyaaltı ilçesinde: Sarısu, Hurma, Liman, Mollayusuf, Gürsu Mahallelerinde; Kepez ilçesinde: Sütçüler,Hüsnü Karakaş, Göksu,Kütüikçü,Kuzeyyaka Mahallelerinde; Muratpaşa ilçesinde: Güzeloba, Çağlayan, Şirinyalı, Demircikara Mahallelerinde ve Döşemealtı ilçesinde: Altınkale, Yeşilbayır, Çıplaklı Mahallelerinde görülmektedir.

\section{Antalya Kent Merkezinde Kentsel Dönüşüm Uygulamaları}

Antalya kent merkezinde dönüşüm uygulamaları; riskli alan ilanı, riskli yapı tespiti ve kentsel dönüşümgelişim proje alanı şeklinde gerçekleştirilmektedir. $\mathrm{Bu}$ bölümde, Antalya kent merkezinde gerçekleştirilen kentsel dönüşüm uygulamaları hakkında bilgi verilecektir.

\section{Sayılı Kanun Kapsamında Riskli Yapı Tespiti}

Antalya Çevre ve Şehircilik İl Müdürlüğü verilerine göre Antalya il sınırları içerisinde 6306 sayılı Afet
Riski Altındaki Alanların Dönüşürüulmesi Hakkında Kanun kapsamında 31 Aralık 2018 tarihi itibari ile 10.125 adet yapı için risk tespit raporu başvurusu yapılmış ve 9.923 adet yapı riskli olarak ilan edilmiştir. Riskli ilan edilen yapılardan 9.329 adedinin yıkımı gerçekleştirilmiştir. Antalya kent merkezinde ise (Kepez, Muratpaşa, Konyaaltı, Aksu, Döşemealtı) 8.512 adet yapı riskli ilan edilmiştir (Tablo 2) [35].

Antalya kent merkezinde riskli olarak ilan edilen yapı adedi, il genelindeki riskli yapıların yaklaşık \%85'ini oluşturmaktadır. Ayrıca, riskli yapı ilan işlemlerinin Kepez ilçesinde yoğunlaştığı görülmektedir. Bu ilçeyi Muratpaşa ilçesi takip etmektedir (Şekil 8).

Tablo.2 Antalya'da ilan edilen riskli yapi istatistikleri [35]

\begin{tabular}{|c|c|c|c|}
\hline & & & \\
\hline ilçe & & Başvuru & Riskli yapı adedi \\
\hline & Kepez & 7.211 & 7.076 \\
\hline$\stackrel{e}{=}$ & Muratpaşa & 1.297 & 1.274 \\
\hline 苞 & Konyaaltı & 57 & 55 \\
\hline 苞 & Aksu & 15 & 15 \\
\hline 西 产 & Dössemealtı & 95 & 92 \\
\hline & Alanya & 310 & 286 \\
\hline & Elmal 1 & 24 & 23 \\
\hline & Finike & 23 & 22 \\
\hline & Gazipaşa & 45 & 40 \\
\hline & Kaş & 9 & 8 \\
\hline & Kemer & 23 & 23 \\
\hline & Korkuteli & 131 & 131 \\
\hline 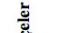 & Kumluca & 41 & 41 \\
\hline 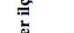 & Manavgat & 649 & 644 \\
\hline$\stackrel{\mathscr{D}}{=0}$ & Serik & 195 & 193 \\
\hline Toplam & & 10.125 & 9.923 \\
\hline
\end{tabular}

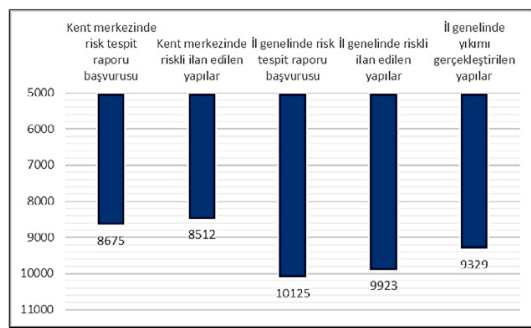

Şekil.8 Antalyảda tespiti yapılan riskli yapılar[35]

6306 sayll kanunun 5. maddesinde yer alan "Anlaşma ile tahliye edilen yapıların maliklerine veya malik olmasalar bile kiracı veya sinırlı ayni hak sahibi olarak bu yapılarda ikamet edenlere veya bu yapilarda işyeri bulunanlara geçici konut veya işyeri tahsisi ya da kira yardımı yapılabilir." hükmüne istinaden Antalya genelinde 31 Aralık 2018 tarihi itibari ile 127.224.963 TL kira yardımı yapılmıştır [35]. 
Antalya'da 2018 yılı Aralık ayı itibari ile riskli yapı tespiti işlemlerini yürütmek için Çevre ve Şehircilik Bakanlığı'nca yetkilendirilmiş 31 adet kuruluş bulunmaktadır. Bu kuruluşlar arasında yapı denetim firmaları, yapı laboratuvarları ve mühendislik şirketleri yer almaktadır.

\subsection{Sayılı Kanun Kapsamında İlan Edilen Riskli Alanlar}

Antalya kent merkezinde 6306 sayılı Afet Riski Altındaki Alanların Dönüsstürülmesi Hakkında Kanun kapsamında üç adet kentsel dönüșüm ve riskli alan ilanı gerçekleștirilmiștir. Bakanlar Kurulunca ilan edilen alanlar, Kepez ilçe sınırları içerisinde yer almaktadır. $\mathrm{Bu}$ alanlar toplam 149,06 ha olup, ilan edilen yıla ait ADNKS (Adrese Dayalı Nüfus Kayıt Sistemi) verilerine göre 16.057 kişilik nüfusu etkilemektedir [36,37, $38,39]$.

Tablo.3 Antalya kent merkezinde 6306 Sayilı Kanun kapsamında ilan edilen riskli alanlar [33, $36,38,39]$ ] (*ADNKS 2014 yılı verileri, ***Veri yoktur)

\begin{tabular}{lllll}
\hline Ilçe & Kararlaștırlan alan & $\begin{array}{l}\text { Alan } \\
\text { mikktarn } \\
\text { (ha) }\end{array}$ & $\begin{array}{l}\text { Etkilenen } \\
\text { nüfus }\end{array}$ & Kanun kapsamı \\
\hline Kepez & $\begin{array}{l}\text { Kepez ve Santral } \\
\text { Mahalleleri }\end{array}$ & 132,70 & $* 10.915$ & $\begin{array}{l}6306 \text { sayilı kanun 2. } \\
\text { maddesi }\end{array}$ \\
\hline Kepez & Gülveren Mahallesi & 6,59 & $* * 5.142$ & $\begin{array}{l}6306 \text { sayill kanun 2.- } \\
\text { ek 1. maddeleri }\end{array}$ \\
\hline Kepez & Günes Mahallesi & 9,77 & $* * *$ & $\begin{array}{l}\text { 6306 sayill kanun ek } \\
1 \text { maddesi }\end{array}$ \\
\hline
\end{tabular}

\subsubsection{Kepez İlçesi Kepez ve Santral Mahalleleri riskli alan ilanı ve kentsel dönüşüm projesi}

Antalya kent merkezinde 6306 sayll kanun kapsamında "riskli alan" ilan edilerek kentsel dönüşüm projesi uygulanan ilk bölge, Kepez ilçesindeki Kepez ve Santral Mahallelerini kapsamaktadır (Şekil 9). Bölge, Bakanlar Kurulu'nun 24.11.2014 tarih ve 2014/7041 sayılı kararı ile riskli alan ilan edilmiş ve karar 25.12.2014 tarih ve 29216 sayllı Resmi Gazete'de yayımlanarak yürürlüğe girmiştir [37]. Riskli olarak ilan edilen alan 132,70 ha olup 3.245 hak sahibini içeren toplam 10.915 kişilik nüfusa sahiptir [36, 37, 40]. Kepez ve Santral Mahalleleri, anakentin kuzey kesiminde Antalya-Burdur karayolunun batı yönünde yer almakta olup anakent yerleşiminin yoğun olarak gözlendiği ilk terasın sınırını oluşturmaktadır. Bölgede, genellikle bir ve iki katlı konutların oluşturduğu sağlıksı ve plansız yapılaşma bulunmaktadır.

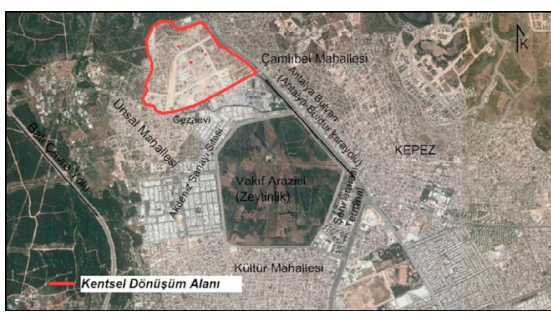

Şekil.9 Kepez ve Santral Mahalleleri riskli alan sınırı

Söz konusu riskli alanda gerçekleștirilecek kentsel dönüşüm proje işlemleri yetkisi, 29.12.2014 tarihinde Çevre ve Şehircilik Bakanlı̆̆ı'nca Antalya Büyükşehir Belediyesi'ne devredilmiştir. Riskli alan kapsamında uygulanacak olan kentsel dönüşüm projesini ve maliklere ait kullanım haklarını belirleyen 1/25.000 ölçekli Nazım İmar Planı Değişikliği, 09.10.2015 tarihli Büyükşehir Belediyesi Meclis kararı ile 1/100.000 ölçekli Antalya-Burdur-Isparta Bölgesi Çevre Düzeni Planına uygun olarak kabul edilmiştir. Bu çerçevede 1/5.000 ölçekli Revizyon Nazım İmar Planı hazırlanmış ve 08.12.2015 tarihinde Büyükşehir Belediyesi Meclis kararı ile onaylanmıştır. 1/1.000 ölçekli Uygulama İmar Planı onaylanması akabinde yıkım işlemleri gerçekleştirilerek inşaat sürecine başlanmıştır [40].

$\mathrm{Bu}$ alanlarda yaşayan vatandaşların tam katılımıyla oluşturulan dönüşüm projesi, kamuözel şirket ortaklığı şeklinde devam etmektedir. Proje, Antalya'da 6306 sayılı kanun kapsamında gerçekleştirilen ilk dönüşüm projesidir. Dönüşüm kapsamında daha önceden aynı bölgede yaşayan ve hak sahibi olan vatandaşlar da Büyükşehir Belediyesince düzenlenen imar planı revizyonlarını oylayarak kabul etmiş ve aynı proje kapsamında konut sahibi olmuşlardır. Bu durum, ilgili kentsel dönüşüm uygulaması ile “yerinde dönüşümün” gerçekleştirildiğini ortaya koymaktadır. Diğer bir ifadeyle, uygulanan proje ile 6306 sayılı kanunun her zaman eleştirildiği tarafı olan "vatandaşların yaşadığı mahalleden uzaklaştırılmaları ve mahalle kültürünün yok edildiği" eleştirilerinin bertaraf edildiği bir kentsel dönüşüm sağlanmıştır. 


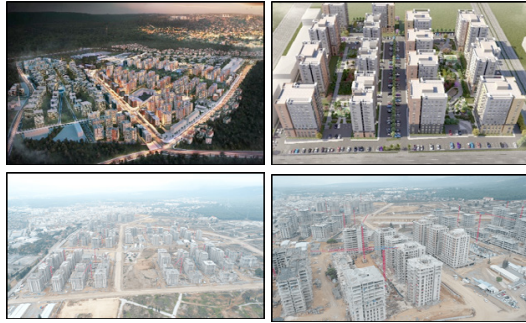

Şekil.10 Kepez ve Santral Mahalleleri kentsel dönüşüm alanına ait proje görselleri ve inşaat görünümü $[40,41]$

Proje kapsamında; konut, ticaret, akaryakıt ve servis istasyonu, eğitim tesisi ve sağlık merkezi alanları bulunmaktadır. Buna ilaveten, hâlihazırda şehir içi ulaşımda kullanılan raylı sistem hattının dönüşüm alanına bağlantısını sağlayacak depolama alanları ile istasyon ve teknik altyapı tesisleri de proje dâhilindedir (Şekil 10). 1/1.000 ölçekli Uygulama İmar Planı kapsamında, proje alanı içerisinde 26 ha büyüklüğündeki alan yeşil alan, rekreasyon alanı ve meydan düzenlemelerine ayrılmıştır. Projede yaklaşık 79 ha büyüklüğündeki alan ise konut ve ticaret alanı şeklinde planlanmıştır [40].

\subsubsection{Kepez İlçesi Gülveren Mahallesi riskli alan ilanı ve kentsel dönüşüm projesi}

Kepez ilçe sinırları içerisinde bulunan Gülveren Mahallesi, 6306 sayılı kanun kapsamında Bakanlar Kurulu'nun 12.12.2016 tarih ve 2016/9615 sayll kararı ile riskli alan ilan edilmiş ve karar 03.01.2017 tarih ve 29937 sayılı Resmi Gazete'de yayımlanarak yürürlüğe girmiştir [38]. Alan 6,59 ha büyüklüğe sahiptir (Şekil 11).

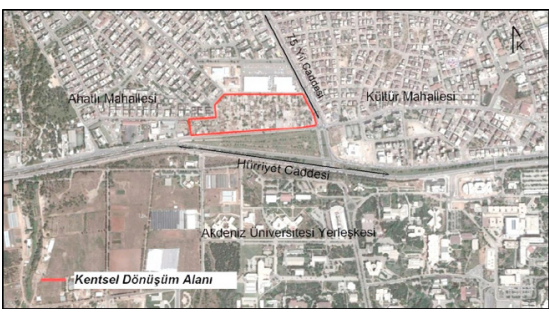

Şekil.11 Gülveren Mahallesi riskli alan sınırı

Söz konusu kentsel dönüşüm projesi işlemlerini yürütme yetkisi Kepez Belediyesi'ne aittir. Projenin uygulanacağı alanda 160 gecekondu ve 135 hak sahibi mevcuttur. Hâlihazırda 135 hak sahibi ile anlaşma sağlanmış ve yıkım işlemleri gerçekleştirilmiştir. İlgili alanda 20 Mart 2018 tarihinde kat karşlığı inşaat ihalesi yapılmış ancak sonuçlandırılamamıştır. İkinci ihale 8 Ekim
2018 tarihinde gerçekleştirilmiştir. İhale öncesi inşaat paylaşım oranları; \%47 idare (Kepez Belediyesi), \%53 yüklenici şeklinde belirlenmiştir [42]. Kentsel dönüşü̈m projesinin uygulanacağı alan, Akdeniz Üniversitesi ana yerleşkesinin kuzeyinde konumlanmış olup, 2018 yılında trafiğe açılan Batı Çevreyoluna yaklaşı 1,5 km mesafededir.

\subsubsection{Kepez İlçesi Güneş Mahallesi riskli alan ilanı ve kentsel dönüşüm projesi}

Kepez ilçe sınırlanı içerisinde bulunan Güneş Mahallesi’nin mülkiyeti Antalya Büyükşsehir Belediyesi adına kayıtlı 9,77 ha'lık bölümü (Şekil 12), 6306 sayılı kanun kapsaminda Bakanlar Kurulu'nun 27.12.2016 tarih ve 2016/9724 sayılı kararı ile riskli alan ilan edilmiş ve karar 20.01.2017 tarih ve 29954 sayll Resmi Gazete'de yayımlanarak yürürlüğe girmiştir [39, 42]. Söz konusu kentsel dönüşüm projesi işlemlerini yürütme yetkisi Antalya Büyükşehir Belediyesi'ne aittir. Hak sahipleriyle yapılan ön protokol işlemleri ve bölgede bulunan gecekondu türü yapıların yıkım işlemleri tamamlanmıştır. Riskli alan ilan edilen bölgede 690 adet daireden oluşan Kepez Toptancı Hali Sosyal Konut Projesi hayata geçirilecektir. Projenin inşası için kat karşllı̆̆ inşaat ihalesi 16 Ağustos 2018 tarihinde gerçekleştirilmiştir. İhale öncesi inşaat paylaşım oranları; $\% 45$ idare (Büyükş̧ehir Belediyesi), \%55 yüklenici şeklinde belirlenmiştir [43].

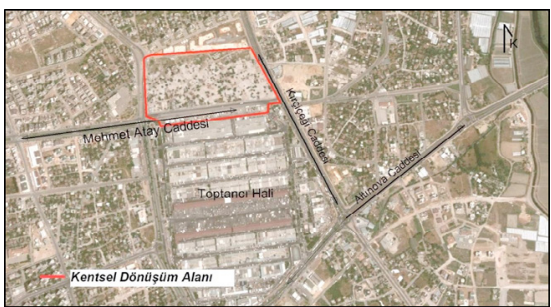

Şekil.12 Güneş Mahallesi riskli alan sınırı

\subsection{Sayılı Kanun Kapsamında İlan Edilen Dönüşüm ve Gelişim Alanları}

Antalya kent merkezinde 5393 sayll Belediye Kanununun 73. Maddesi kapsamında üç adet kentsel dönüşüm ve gelişim proje alanı ilanı yapılmıştır. Kanunun 73. Maddesinde, "Belediye, belediye meclisi kararıyla; konut alanları, sanayi alanlan, ticaret alanları, teknoloji parklan, kamu hizmeti alanları, rekreasyon alanları ve her türlü sosyal donatı alanları oluşturmak, eskiyen kent kısımlarını yeniden inşa ve restore etmek, kentin tarihi ve kültürel dokusunu korumak veya deprem riskine karşı 
tedbirler almak amaciyla kentsel dönüşüm ve gelişim projeleri uygulayabilir... Ancak, kamunun mülkiyetinde veya kullanımında olan yerlerde kentsel dönüşüm ve gelişim proje alanı ilan edilebilmesi ve uygulama yapılabilmesi için ilgili belediyenin talebi ve Cumhurbaşkanınca (02.07.2018 tarihli 703 sayılı KHK öncesi: Çevre ve Şehircilik Bakanlığının teklifi üzerine Bakanlar Kurulunca) bu yönde karar alınması şarttır." hükmüne istinaden Antalya Büyükşehir Belediyesince, Aksu ilçe sınırları içerisinde yer alan muhtelif bölgeler kentsel dönüşüm ve gelişim proje alanı ilan edilmesi talebinde bulunulmuştur. Buna istinaden Bakanlar Kurulunun bila kararları ile Tablo 4'te belirtilen alanlar kentsel dönüşüm ve gelişim proje alanı olarak ilan edilmiştir.

Tablo.4 Antalya kent merkezinde 5393 Sayılı Kanun kapsamında ilan edilen dönüşüm alanları [43, 44, 45]

\begin{tabular}{|c|c|c|c|}
\hline illçe & Kararlaştırılan alan & Alan (ha) & Kanun kapsamı \\
\hline Aksu & $\begin{array}{l}\text { Altıntaş, Hacialiler, Calkaya } \\
\text { Mahalleleri }\end{array}$ & 486,00 & $\begin{array}{c}5393 \text { sayll kanun } 73 . \\
\text { maddesi }\end{array}$ \\
\hline Aksu & $\begin{array}{l}\text { Altuntaş, Kemerağzl, Mandırlar } \\
\text { Mahalleleri }\end{array}$ & 475,00 & $\begin{array}{c}5393 \text { sayll kanun } 73 . \\
\text { maddesi }\end{array}$ \\
\hline Aksu & $\begin{array}{l}\text { Altuntass, Güzelyurt, Mandirlar, } \\
\text { Hacıaliler Mahalleleri }\end{array}$ & 428,00 & $\begin{array}{c}5393 \text { sayili kanun } 73 . \\
\text { maddesi }\end{array}$ \\
\hline
\end{tabular}

4.3.1 Aksu İç̧esi Altıntaş, Hacialiler, Çalkaya Mahalleleri (1. Etap) kentsel dönüşüim ve gelişim proje alanı ilanı

Aksu ilçe sınırları içerisinde bulunan Altıntaș, Hacıaliler, Çalkaya Mahallelerinin bir bölümü (Şekil 13), 5393 sayılı Belediye Kanununun 73. maddesi kapsaminda Bakanlar Kurulu'nun 09.04.2018 tarih ve 2018/11605 sayılı kararı ile kentsel dönüşüm ve gelişim alanı ilan edilmiş ve karar 29.05.2018 tarih ve 30435 sayılı Resmi Gazete'de yayımlanarak yürürlüğe girmiştir [44]. Proje alanı olarak ilan edilen alan 486,00 ha büyüklüğündedir.

43.2 Aksu İcçesi Altıntaş, Kemerağð̆, Mandırlar Mahalleleri (2. Etap) kentsel dönüşüim ve gelişim proje alanı ilanı

Aksu ilçe sınırları içerisinde bulunan Altıntaş, Kemerağzı, Mandırlar Mahallelerinin bir bölümü (Şekil 13), 5393 sayılı Belediye Kanununun 73. maddesi kapsaminda Bakanlar Kurulu'nun 09.04.2018 tarih ve 2018/11606 sayılı kararı ile kentsel dönüşüm ve gelişim alanı ilan edilmiş ve karar 29.05.2018 tarih ve 30435 sayılı Resmi Gazete'de yayımlanarak yürürlüğe girmiştir [45]. Proje alanı olarak ilan edilen alan 475,00 ha'dır.
4.33 Aksu İlçesi Altıntaş, Güzelyurt, Mandırlar, Hacialiler Mahalleleri (3. Etap) kentsel dönüşüim ve gelişim proje alanı ilanı

Aksu ilçe sınıları içerisinde bulunan Altıntaş, Güzelyurt, Mandırlar, Hacialiler Mahallelerinin bir bölümü (Şekil 13), 5393 sayll Belediye Kanununun 73. maddesi kapsaminda Bakanlar Kurulu'nun 09.04.2018 tarih ve 2018/11607 sayılı karanı ile kentsel dönüşüm ve gelişim alanı ilan edilmiş ve karar 29.05.2018 tarih ve 30435 sayılı Resmi Gazete'de yayımlanarak yürürlüğe girmiştir [46]. Proje alanı olarak ilan edilen alan 428,00 ha büyüklüğündedir.

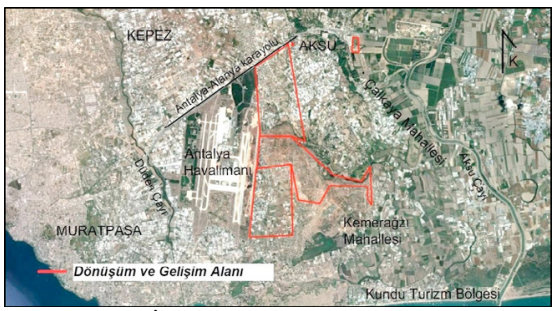

Şekil.13 Aksu İlçesinde ilan edilen dönüşüm alanları

\subsection{Sağlıklaştırma ve Yeniden Canlandırma Projeleri}

Antalya kent merkezinde, 6306 ve 5393 sayılı kanunlar kapsamında ilan edilen riskli ve dönüşüm alanlarında uygulanan (veya uygulanması planlanan) kentsel dönüşüm projelerine ilaveten, muhtelif tarihi alanlarda ve caddelerde mevcut yapısal dokunun iyileştirilmesi amacıyla sağlıklaştırma ve yeniden canlandırma projeleri de hayata geçirilmiştir. $\mathrm{Bu}$ projeler ile şehrin tarihi dokusu içerisinde yer alan, mekânsal dokusu eskiyen ve kentin gelişimiyle beraber canlılığını yitiren alanların kent içerisinde daha etkin kullanımı amaçlanmıştır. Kent merkezi içerisinde gerçekleştirilen sağlıklaştırma ve yeniden canlandırma projelerinden muhtelif örnekler Tablo 5'te sunulmuştur.

Tablo.5 Antalya kent merkezinde gerceklestirilen sağlıklaştırma ve yeniden canlandırma projeleri [47]

\begin{tabular}{|c|c|}
\hline Proje adı & Proje yeri \\
\hline Ali Çetinkaya Caddesi Kentsel Tasarım Projesi & Muratpaşa/Çaybașıı Mahallesi \\
\hline Balbey Mahallesi Kentsel Yenileme Projesi & Muratpașa/Balbey Mahallesi \\
\hline Boğaçayı Çevre Düzenlemesi Projesi & $\begin{array}{l}\text { Konyaalt//Hurma-Liman } \\
\text { Mahalleleri }\end{array}$ \\
\hline $\begin{array}{l}\text { Cumhuriyet Meydanı ve Tophane Cay Bahçesi } \\
\text { Düzenleme Projesi }\end{array}$ & Muratpaşa/Selçuk Mahallesi \\
\hline $\begin{array}{l}\text { Doğu Garajı Kültür Merkezi ve Nekropol Alanı } \\
\text { Projesi }\end{array}$ & allesi \\
\hline Kaleiçi Hıdırlık Sokak Kentsel Tasarım Projesi & Muratpaşa/Selçuk Mahallesi \\
\hline Konyaaltı Sahil Projesi & Konyaalt//Konyaaltı Sahili \\
\hline Millet Bahçesi Projesi (eski Şehir Stadı) & Muratpaşa/Gençlik Mahallesi \\
\hline Serdengecti Park1 (eski İ Özel İdaresi Binas1) & Muratpaşa/Kısla Mahallesi \\
\hline Sobacilar Carşı1s & Muratpaşa/Balbey Mahallesi \\
\hline $\begin{array}{l}\text { Şarampol Caddesi Kentsel Tasarım ve Cevre } \\
\text { Düzenlemesi Projesi }\end{array}$ & Muratpaşa/Muratpaşa Mahallesi \\
\hline
\end{tabular}


Söz konusu projeler arasında ülkemizde ilk olma özelliğini taşıyan uygulamalar da mevcuttur. Doğu Garajı Kültür Merkezi ve Nekropol Alanı Projesi, başlangıçta sosyal donatıları ile birlikte oluşturulacak kültür merkezi inşasını kapsamaktaydı. Proje kapsamında yürütülen kazı çalışmalarında ortaya çıkan ve antik döneme tarihlenen nekropol, projede değişikliğe gidilmesine neden olmuş ve bu alan tamamen koruma altına alınarak müze haline getirilmiştir. Ayrıca, kazı çalışmaları neticesinde ortaya çıkarılan buluntular, Ali Çetinkaya Caddesi Kentsel Tasarım Projesi kapsamında yeniden düzenlenen caddede sergilenmektedir (Şekil 14). Proje kapsamında, cadde üzerinde yer alan işyeri tabelaları kaldırılmış, binaların dış cephe boyası ve kaplama imalatları yenilenmiş ve engelli ulaşımına uygun yaya yolları yapılmıştır.

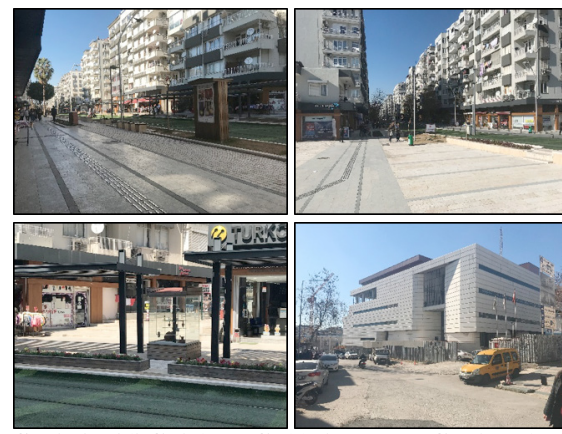

Şekil.14 Ali Çetinkaya Caddesi ve Doğu Garajı Kültür Merkezi ve Nekropol Alanı

\section{Sonuç ve Öneriler}

1980'li yıllarda tarım ağırlıklı şehir ekonomisine sahip Antalya, bölgedeki turizm alanları ilanı ve sanayi yatırımları ile birlikte göç almaya başlamış ve nihayetinde 1980 y1lında 259.905 (merkez ilçe ve bağlısı bucaklar) olan kent merkezi nüfusu; 1990 yılında 448.773, 2000 yılında ise 714.219 kişiye ulaşmıştır. Günümüzde ise kent merkezi nüfusu 1980 yılına göre yaklaşı 6 kat artarak 1.311.471 kişi olmuştur [36]. Kent nüfusunun artışı beraberinde plansız ve altyapısı yetersiz yapılaşmayı getirmiştir. Plansız ve sağlıksız yapılaşma, özellikle kentin kuzey kesimlerinde, yıllar içinde artarak genişlemiş ve günümüzde kent merkezinin yayılma alanına yapay bir bariyer oluşturmuştur. Göç hareketlerinin gelecek dönemlerde de artarak devam edebileceği düşünülürse, kent merkezine yerleşecek olan nüfusun konut ihtiyacının karşılanması için ihtiyaç duyulacak yeni imar alanlarının oluşturulabilmesi amacıyla yapay bariyer durumundaki bu bölgelerin, kentsel dönüşüm mevzuatı kapsamında tasfiye edilmesi gerektiği görülmektedir. Buna ilaveten; kentin ilk yerleşim yerlerinde yer alan yapıların büyük bir çoğunluğunun günümüzde yürürlükte olmayan yapı kuralları ile inşa edildiği bilinmektedir. Günümüz imar koşullarına da uymayan bu yapılaşma alanlarının afetlere karşı dirençli hale getirebilmek için güvenli yaşam çevrelerine dönüştürülmesi gerekmektedir. Bütün bu hususlar, hem plansız ve sağlıksız yapılaşma alanlarının hem de eski yapıları içerir bölgelerin kentsel dönüşüme tabi tutulması gerektiğini ortaya koymaktadır.

Nitekim 6306 sayılı kanunun yürürlüğe girmesi ile birlikte Antalya kamuoyunda bu alanların yenilenmesi isteği uyanmıştır. Bu kapsamda, 2014 yılında kent merkezinin kuzey kesimlerinde yer alan Kepez ve Santral Mahallelerinde Antalya'nın ilk kentsel dönüşüm projesi için adım atılmıştır. Sonrasında kent içerisindeki riskli alanların ve riskli yapıların yenilenmesi amacıyla birçok uygulama gerçekleştirilmiştir. Antalya kent merkezinde gerçekleştirilen kentsel dönüşüm uygulamaları aşağıdaki şekilde özetlenebilir

- Kent merkezinde ilan edilen 6 dönüşüm alanının 3 tanesi 6306 sayılı kanun kapsamında iken diğer 3 tanesi 5393 sayılı kanun kapsamındadır.

- Kentte rezerv yapı alanı ilanı bulunmamaktadır.

- 6306 sayılı kanun kapsamında ilan edilen riskli alanların tamamı Kepez ilçesinde, 5393 sayılı kanun kapsamında yer alan dönüşüm alanlarının tamamı ise Aksu ilçesinde yer almaktadır.

- Tüm riskli alan ve dönüşüm/gelişim alanları, yerel yönetimlerce (Büyükşehir ve ilçe belediyeleri) önerilmiştir.

- Risklialanolarakilan edilen 3 adetbölgede planlanan dönüşüm projelerine ait işlemleri gerçekleştirme yetkisi, Çevre ve Şehircilik Bakanlığı'nca yerel yönetimlere devredilmiştir.

- Tüm dönüşüm projeleri için arsa payı karşılığı inşaat işleri kapsamında ihale ilanları ilgili belediyelerce yayınlanmıştır.

- 6306 sayılı kanun yardımıyla ilan edilen riskli alanlarda, hak sahibi olarak tespit edilenlere Belediyelerce oluşturulan kentsel dönüşüm projeleri kapsamında mülkiyet hakkı verilmiştir. Diğer bir deyişle; riskli alan ilan edilen bölgelerde yaşayanlar dönüşüm sonrasında da yine aynı bölgede yaşamaya devam edeceklerdir.

- Sağlıklaştırma ve yeniden canlandırma projeleri, kent merkezinin 1950'li ve 1960'lı yıllarda da yerleşim alanı olan mahallelerde gerçekleştirilmiştir. 
- Kent merkezinde toplam 8.675 adet riskli yapı tespiti başvurusu yapılmıştır. 7.211 adet başvuru ile Kepez ilçesi en fazla başvuru yapılan bölge durumundadır. Kepez'de ilan edilen riskli yapılar, kent merkezinde ilan edilen tüm riskli yapıların \%83'ünü oluşturmaktadır. Bu oran Antalya ilinin tamamında \%71'dir. Bu durum; Kepez ilçesinde sağlıksız ve plansız yapılaşma sonucu oluşan yapı stokunun yenilenmesine duyulan ihtiyacı göstermektedir.

Ylllar içerisinde sürekli gelişen ve bununla birlikte nüfusu artan Antalya kent merkezinde dönüştürülmesi muhtemel alanların varlığı göze çarpmaktadır. Ancak, kentsel dönüşüm uygulamalarının yasal dayanağı olan 6306 sayılı kanunun yürürlüğe girdiği 2012 yılından 2019 yılına dek, kanun kapsamında sadece üç adet alan riskli ilan edilmiştir. Mevcut rantın yüksek olması ve dönüşüm sonrasında yaşanması muhtemel rant artışı, kent merkezinde dönüşüm sürecinin yavaş seyretmesinin nedenleri arasında sayılabilir. Nitekim, 1990'lı yıllarda turizm sektörünün hızlı gelişimi ile birlikte kentte oluşan rant artışı, turizm tesis alanı olarak planlanan bölgelerin konut alanına dönüştürülmesine sebep olmuştur. Aynı durumun, kentsel dönüşüm projeleri sonrasında da yaşanması muhtemeldir.

Antalya kent merkezinin 1950'li yıllardaki yerleşim alanında yer alan bölgelerde, sağlıklaştırma ve yeniden canlandırma proje yatırımlarının artırılması kent siluetinin yenilenmesini de sağlayacaktır. Gerçekleştirilen projeler, kenti cazibe merkezi haline dönüştürerek turizm potansiyeline de olumlu yönde etki edebilir.

Bölgesinde göç alan il konumunda bulunan Antalya, tarım arazilerini, doğal ve arkeolojik sit alanlarını, turizm tesislerini ve sanayi bölgelerini bir arada barındırmaktadır. Kent merkezinin yayılma alanının genişlemesi, kentin doğu ve batı yönlerinde yer alan sırasıyla Aksu ve Konyaaltı ilçelerindeki tarım arazilerinin yeni imar alanlarına dönüştürülmesi yönünde baskı oluşturmaktadır. Mevcut gecekondu bölgeleri ile eski yapıları içerir alanların tasfiye edilip yenilenmesi, bu baskının ortadan kaldırılmasına veya daha ileri ki dönemlere ertelenebilmesine imkân sağlayacaktır. Böylelikle; tarım arazileri korunabilecek, eskimiş ve yıpranmış kent dokusu yenilenebilecek, gecekondu bölgeleri bertaraf edilerek sağlıklı yapılaşma alanları oluşturulabilecek, kentin afetlere dirençli hale getirilmesi sağlanabilecektir. Kent yerleşim alanının mevcut alanların dönüşümü sayesinde artmaması, belediyelerin daha hızlı ve etkin hizmet verebilmesine de katkıda bulunacaktır.

Ayrıca, kentsel dönüşüm projelerinin, kentin bir bütün olarakele alınıp gelecek perspektifinin oluşturulması için bir firsat olarak görülmesi gerekmektedir. Bu kapsamda, kentmerkezinde konutalanlarının arasındakalmış sanayi alanlarının da başka konumlara taşınması ve bunun sonucunda oluşacak alanların sosyal donatı alanlarına veya afet toplanma alanlarına dönüştürülmeleri uygun olacaktır. Ayrıca, kent merkezine ait "Deprem Mastır Planını"" hazırlanması kentin gelecekteki gelişimine de katkı sağlayacağı açıktır. Antalya kent merkezinde hayata geçirilen kentsel dönüşüm projeleri, bölgedeki nüfusu yoğunlaştıracak şekilde gerçekleştirilmektedir. $\mathrm{Bu}$ durumun, 2019 yılının başından bu yana ülke kamuoyunun gündemindeki yatay mimari tartışmaları ile çeliştiği görülmektedir. Avrupa ülkelerinin yıllar önce çok yüksek katlı ve yoğun nüfusu barındırabilecek dönüşüm uygulamalarından vazgeçtiği bilinmektedir [48]. Sadece ticari kaygilar ve piyasa dinamikleri göz önüne alınarak gerçekleştirilen uygulamalar, kent içerisinde başkaca sorunların artmasına zemin oluşturabileceği ifade edilebilir. 


\section{KAYNAKÇA}

[1] YILMAZ, M., (2015), “Türkiye'de Kırsal Nüfusun Değişimi ve İllere Göre Dağıllımı (1980-2012)”, Doğu Coğrafya Dergisi, 20 (33), 161-188.

[2] BULUT, İ., CEYLAN, S., (2013), “Kentsel Dönüşüm Yaklaşımlarına Bir Örnek: Efendibey (Niğde) Kentsel Dönüşüm Uygulaması”, Atatürk Üniversitesi Sosyal Bilimler Enstitüsü Dergisi, 17 (1), 239-256.

[3] ÇELIKBIILEK, A., ÇAKIR ÖZTÜRK, Ş.M., (2017), "6306 Sayılı Kanun Kapsamında Yürütülen Kentsel Dönüşüm Çalışmaları ve İzmir Uygulamaları”, Medeniyet Sanat İstanbul Medeniyet Üniversitesi Sanat, Tasarım ve Mimarlık Fakültesi Dergisi, 3 (2), 187-213.

[4] TDY (2007), Deprem Bölgelerinde Yapılacak Binalar Hakkında Yönetmelik, T.C. Bayındırlık ve İskân Bakanlığı, Ankara.

[5] TBDY (2019), Türkiye Bina Deprem Yönetmeliği, Afet ve Acil Durum Yönetimi Başkanlı̆̆ı, Ankara.

[6] DAŞKIRAN, F., AK, D., (2015), “6306 Sayılı Kanun Kapsamında Kentsel Dönüşüm”, Yönetim ve Ekonomi Araştırmaları Dergisi, 13 (3), 264-288.

[7] ÇŞB (2012), 6306 sayılı Afet Riski Altındaki Alanların Dönüştürülmesi Hakkında Kanun, T.C. Çevre ve Şehircilik Bakanlı̆̆ı, Ankara.

[8] ŞIŞMAN, A., KİBAROĞLU, D., (2009), “Dünyada ve Türkiye'de Kentsel Dönüşüm Uygulamaları”, 12. Türkiye Harita Bilimsel ve Teknik Kurultayı, 11-15 Mayıs, Ankara.

[9] ERGUN, C., GÜL, H., (2010), "Barınma Hakkının İhlal Edilme Sürecinde Kentsel Dönüşüm Projeleri”, 2. Sosyal Haklar Ulusal Sempozyumu, 4-6 Kasım, Denizli.

[10] URL-1 (2018), Türk Dil Kurumu, http://www.tdk.gov.tr/, [Erişim Tarihi: 14 Mart 2018]

[11] AKIŞ, A., (2011), "Turizmin Kentsel Gelişim Üzerine Etkileri: Bir Örnek İnceleme AntalyaTürkiye”, Doğu Coğrafya Dergisi, 16 (25), 193-206.

[12] KAYA, H.E., (2009), “Kentsel Dönüşüm Projeleri ve Halk Katılımı”, Toplum ve Demokrasi, 3 (6-7), 203-216.

[13] YENICE, M.S., (2014), “Türkiye'nin Kentsel Dönüşüm Deneyiminin Tarihsel Analizi”, Balıkesir Üniversitesi Fen Bilimleri Enstitüsü Dergisi, 16 (1), 76-88.

[14] GENÇ, F.N., (2008), “Türkiye'de Kentsel Dönüşüm: Mevzuat ve Uygulamaların Genel Görünümü”, Yönetim ve Ekonomi Dergisi, 15 (1), 115-130.

[15] USLU, G., UZUN, B., (2014), “Kentsel Dönüşüm Projelerinde Deprem Etkisi”, Harita Teknolojileri Elektronik Dergisi, 6 (2), 1-11.

[16] URL-2 (2018), Çevre ve Şehircilik Bakanlığı Mevzuat Bilgi Sistemi, http://apps.csb.gov.tr/mevzuat/, [Erişim Tarihi: 03 Ekim 2018]

[17] URL-3 (2018), http://www.wikiwand.com/tr/Antalya\%27n\%C4\%B1n_il\%C3\%A7eleri, [Erişim Tarihi: 06 Ekim 2018]

[18] AÇŞM (2011), Antalya İl Çevre Durum Raporu 2011, Antalya Çevre ve Şehircilik İl Müdürlüğü. 
[19] TMMOB Jeoloji Mühendisleri Odası (2018), Antalya Büyükşehir Belediyesi Boğaçay Projesi Değerlendirme Raporu.

[20] URL-4 (2018), Türkiye İstatistik Kurumu, http://www.tuik.gov.tr/, [Erişim Tarihi: 15 Mart 2018]

[21] URL-5 (2018), T.C. İçişleri Bakanlığı Mülki İdare Birimleri, https://www.e-icisleri.gov.tr/Anasayfa/ MulkiIdariBolumleri.aspx, [Erişim Tarihi: 20 Mart 2018]

[22] BİB (1996), Türkiye Deprem Bölgeleri Haritası (18.04.1996) Yerleşim Birimleri ve Deprem Bölgeleri, Bayındırlık ve İskân Bakanlığı Afet İşleri Genel Müdürlüğü Deprem Araştırma Dairesi Başkanlığı.

[23] PAMPAL, S., ÖZMEN, B., (2007), “Türkiye Deprem Bölgeleri Haritalarının Gelişimi”, 6. Ulusal Deprem Mühendisliği Konferansı, 16-20 Ekim, İstanbul.

[24] AFAD (2018), Türkiye Deprem Tehlikesi Haritası (TDTH), Afet ve Acil Durum Yönetim Başkanlığı, Ankara.

[25] URL-6 (2018), Boğaziçi Üniversitesi Kandilli Rasathanesi ve Deprem Araştırma Enstitüsü Bölgesel Deprem-Tsunami İzleme ve Değerlendirme Merkezi Deprem Bilgi Sistemi, http://www.koeri.boun.edu. tr/sismo/2/son-depremler/debrem-bilgi-sistemi/, [Erişim Tarihi: 28 Eylül 2018]

[26] URL-7 (2018), Maden Tetkik ve Arama Genel Müdürlüğ̈̈, http://www.mta.gov.tr/v3.0/hizmetler/ yenilenmis-diri-fay-haritalari, [Erişim Tarihi: 03 Ekim 2018]

[27] DİPOVA, N., CANGİR, B., (2011), "Antalya İli Yerleşim Alanının Depremselliğinin Araştırılması”, Jeoloji Mühendisliği Dergisi, 35 (2), 93-114.

[28] ÖZMEN, M.T., (2015), "Sel-Taşkın Türkiye ve Antalya”, Kutlu\&Avcı Ofset, Antalya.

[29] URL-8 (2018), Lloyd's City Risk Index 2015-2025, https://www.lloyds.com/cityriskindex/, [Erişim Tarihi: 19 Mart 2018]

[30] MANAVOĞLU, E., (2009), “Antalya Kenti'nin Geçmişten Günümüze Mekânsal Gelişimi ve Planlama Çalışmalarının Değerlendirilmesi”, Planlama TMMOB Şehir Plancıları Odası Yayını, 45 (2), 19-30.

[31] URL-9 (2019), Antalya Büyükşehir Belediyesi 1/25.000 İmar Plan Uygulaması, https://cbsportal. antalya.bel.tr/apps/vatandas-imar/, [Erişim Tarihi: 18 Ocak 2019]

[32] ABB (2017a), Antalya Büyükşehir Belediyesi Aksu, Plan ve Bütçe Komisyonu Raporu (13.09.2017 tarihli), Antalya Büyükşehir Belediyesi, Antalya.

[33] URL-10 (2019), İllere Göre Sit Alanları İstatistiği, http://www.kulturvarliklari.gov.tr/TR-44974/ illere-gore-sit-alanlari-istatistigi.html, [Erişim Tarihi: 18 Ocak 2019]

[34] RG (2015), Antalya İli, Muratpaşa İlçesi, Balbey Mahallesi Sınırları İçerisinde Bulunan Alanın Yenileme Alanı Olarak Kabul Edilmesi Hakkında Karar, Resmi Gazete tarih/sayı: 24.04.2015/29336.

[35] AÇŞM (2019), Antalya Çevre ve Şehircilik İl Müdürlüğü Altyapı ve Kentsel Dönüşüm Şube Müdürlüğü arşiv bilgileri. 
[36] URL-11 (2018), TÜiK Merkezi Dağıtım Sistemi, https://biruni.tuik.gov.tr/medas/, [Erişim Tarihi: 02 Ekim 2018]

[37] RG (2014), Antalya İli, Kepez İlçesi, Kepez ve Santral Mahalleleri Sınırları İçerisinde Bulunan Alanın Riskli Alan İlan Edilmesi Hakkında Karar, Resmi Gazete tarih/sayı: 25.12.2014/29216.

[38] RG (2017a), Antalya İli, Kepez İlçesi, Gülveren Mahallesi Sınırları İçerisinde Bulunan Alanın Riskli Alan İlan Edilmesi Hakkında Karar, Resmi Gazete tarih/sayı: 03.01.2017/29937.

[39] RG (2017b), Antalya İli, Kepez İlçesi, Güneş Mahallesi Sınırları İçerisinde Bulunan Bazı Alanın Riskli Alan İlan Edilmesi Hakkında Karar, Resmi Gazete tarih/sayı: 20.01.2017/29954.

[40] URL-12 (2018), Antalya Kepez Santral Kentsel Dönüşüm, http://www.yenikepezsantral.com/, [Erişim Tarihi: 26 Mart 2018]

[41] URL-13 (2019). Suryapı Antalya, http://antalya.suryapi.com.tr/, [Erişim Tarihi: 20 Mart 2019]

[42] URL-14 (2018), https://www.ilan.gov.tr/detay-ihale-duyurulari-kiraya-verme-ve-kullanimhakki-ihaleleri-afet-riski-altindaki-alanlarin-donusturulmesi-isi-yaptirilacaktir-kentsel-donusum-projesi-427594.html, [Erişim Tarihi: 09 Ekim 2018]

[43] URL-15 (2018), İhale ilanı. https://www.ilan.gov.tr/detay-ihale-duyurulari-satis-ihaleleri-kentseldonusum-projesi-kat-karsiligi-yapim-isi-yaptirilacaktir-509225.html?archived=true, [Erişim Tarihi: 09 Ekim 2018]

[44] RG (2018a), Antalya İli, Aksu İlçesi Sınırları İçerisinde Bulunan Bazı Alanların Kentsel Dönüşüm ve Gelişim Proje Alanı İlan Edilmesi Hakkında Karar (1. Etap), Resmi Gazete tarih/sayı: 29.05.2018/30435.

[45] RG (2018b), Antalya İli, Aksu İlçesi Sınırları İçerisinde Bulunan Bazı Alanların Kentsel Dönüşüm ve Gelişim Proje Alanı İlan Edilmesi Hakkında Karar (2. Etap), Resmi Gazete tarih/sayı: 29.05.2018/30435.

[46] RG (2018c), Antalya İli, Aksu İlçesi Sınırları İçerisinde Bulunan Bazı Alanların Kentsel Dönüşüm ve Gelişim Proje Alanı İlan Edilmesi Hakkında Karar (3. Etap), Resmi Gazete tarih/sayı: 29.05.2018/30435.

[47] URL-16 (2019), https://www.antalya.bel.tr/, [Erişim Tarihi: 15 Ocak 2019]

[48] KOÇAK, H., TOLANLAR, M., (2008), "Kentsel Dönüşüm Uygulamaları (Aydın ve Afyonkarahisar Örnekleri)", Afyon Kocatepe Üniversitesi İktisadi ve İdari Bilimler Fakültesi Dergisi, 10 (2), 397-415. 